\title{
The Optimal Structural System Selections for Mediterranean Cities Case Study (Famagusta City)
}

\author{
Munther Mohd \\ Department of civil engineering, An Najah National University, Nablus, Palestine.
}

\begin{abstract}
The architect's primary responsibility lies with the design of buildings which are enclosures for human activities. However, building do not exist in isolation, they exist in a spatial, behavioral, and perceptual context. Thus the architect has a direct responsibility for the relationship between building design and building site.

This paper is an introductory survey of the factors that effect the selection of building optimal structural system in Famagusta. The major aim for this study is the concern with the main natural factors that can be presented by climatic conditions, soil properties, and seismic hazard as well as the selection of the optimal structural system for the given site. This research is done to encourage architects to consider all the environmental factors, and types of structures, in the early stages of design, by showing them the major effects of those factors on their design quality, and direct them to solutions of problems related to these factors.
\end{abstract}

Keywords: Optimal Structures, Famagusta, Climate, Earthquake, Soil.

\section{INTRODUCTION}

Architecture is almost one of the oldest professions in the world history, which can be considered as one of the greatest artistic science, it requires a great deal of efforts and at the same time has many criterions that has to be used to create this art.

In history, the roles of the architects were unique. They were artist, technologist, designer and builder at the same time. Architects were responsible from design of the building, design of the structural system, decoration and construction of all design. There were no individual branches for each field of architecture and engineering. At the beginning of the $19^{\text {th }}$ century, industrial revolution started and architecture has been divided into individual branches as designer, engineer, decorators, and constructors.

Today architects are faced with a bewildering array of structural and construction choices that are at once alluring and potentially misleading. Building design professionals of an earlier, simpler time had available only a limited choice of structural methods and materials that impose spatial and visual constraints on the architecture in their society.

The rigorous limitations on building spans and architectural character imposed by these constraints no longer exist. Recent international world expositions have demonstrated that it is possible to construct a building of virtually any shape. The issues then that every architect should consider is not merely how to incorporate structure into buildings, but also how to establish a basis for the selection of appropriate structural method, form, and material (structural system) in relation to building design. Since technological means are at hand to make every structural solution possible, an increasing burden of responsibility has been placed upon architects to make rational choices with respect to structure in buildings. It is natural to say that any structural form of buildings that will be created by an architect must develop a structural mechanism responsive to all forces upon it. Although it is the responsibility of the structural engineer to design the building to be able to withstand all the forces upon it, the design and development of the structural system in relation to a building concept constitutes one of the major formal decisions made by the architect.

An understanding of the natural elements of the site and its locale (seismic hazard, climate and soil) is very important to building design, and plays a vital role in the selection of an optimal structural system. This research is intending to study all of those natural elements of a site in Famagusta that affect the building design as will as the selection of optimal structural system.

\section{LOCATION OF THE STUDY}

Location of the study has been selected from some alternative groups. The most suitable site for study was this location, because of its climatic conditions, soil properties and strategic location. The exact place of this site is in the first $4 \mathrm{~km}$ from entrance of Famagusta City while coming from Nicosia. It is on the high - way of Famagusta - Nicosia. It has a very strategically place, and very close to the Centrum, however it is quiet and accessible place, that is why; local authorities (municipality and urban planning office) would like to use this site for the future for new settlement area. Current political situations were the most effective factor for these considerations. In this respect, it would be very useful study 
International Journal of Engineering Research and Technology. ISSN 0974-3154, Volume 13, Number 10 (2020), pp. 2582-2587

(C) International Research Publication House. https://dx.doi.org/10.37624/IJERT/13.10.2020.2582-2587

for local authorities also to make a confidential decision on this location. The exact study location has been shown in the following figure with hatched zone:

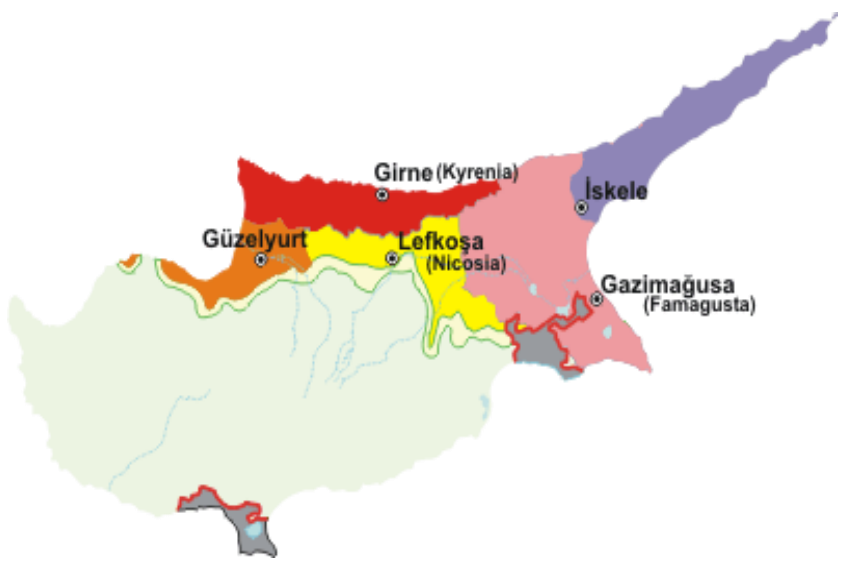

Figure 1. Location of the cities in Cyprus map. (www.emu.edu.tr, [2003])

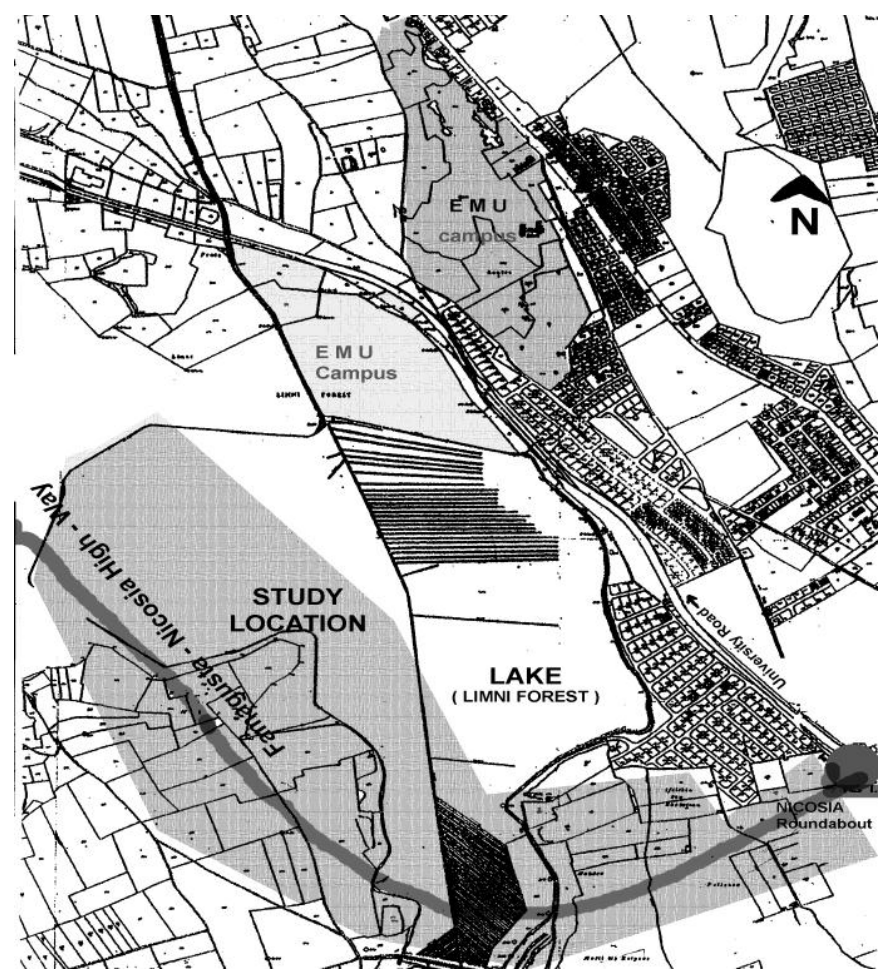

Figure 2. Location of the case selected site. (Dinsev,[2003])

\section{THE MAJOR ENVIRONMENTAL FACTORS THAT EFFECTS THE SITE LOCATION}

\section{- Assessment of Seismic Hazard for Cyprus}

Cyprus is an island which is in the Eastern Mediterranean Sea. This island has many seismic and geological activities in its history. It has been flooded three times in early periods, according to the legends and it has experienced thousands of seismic activities. Usually, the south of the island is very active during it history. It is in the first degree of earthquake zone. In this section, seismic data for Cyprus has been presented only between $20^{\text {th }}$ and $21^{\text {st }}$ centuries.

\section{- Seismic Data Base for Cyprus}

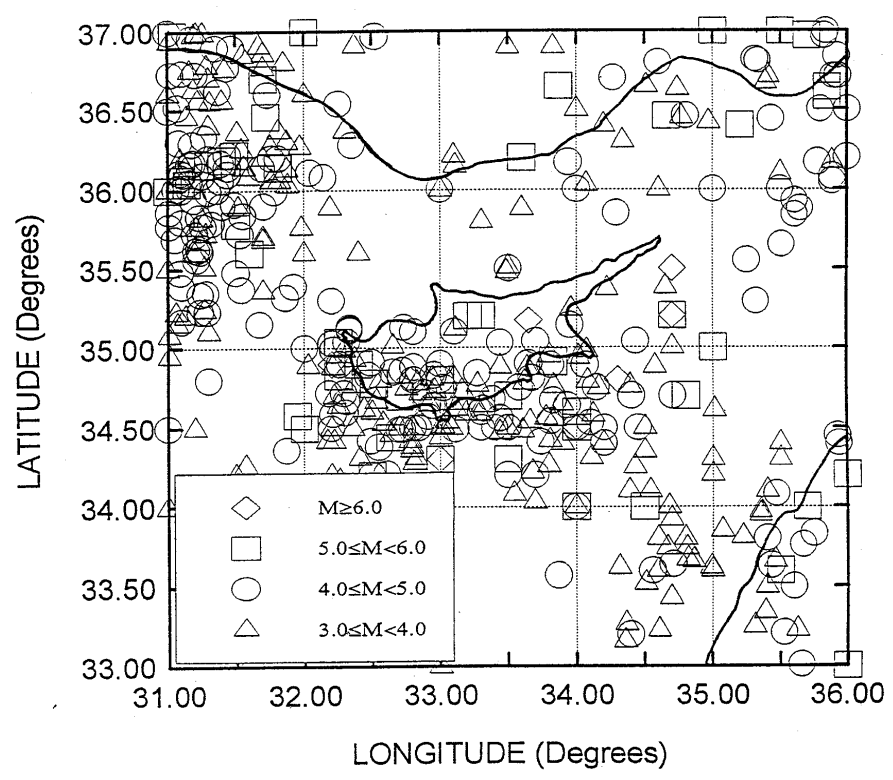

Figure 3. Distribution of earthquake epicenters for the time interval 1896 - 1996. (Can, [1997], p: 71)

As it is shown in the figure above, there are many earthquakes between 1896 - 1996 times. "M" or "Ms" means the frequency (magnitude intervals) of earthquake. $X$ and $y$ direction of figure (table) shows the location of island with latitude and longitude degrees on the earth. Different geometric shapes show different frequency of the occurred earthquakes epicenters on the map.

\begin{tabular}{|c|c|c|c|c|c|c|}
\hline Decade & $\mathrm{M} \geq 6.5$ & $\begin{array}{c}\mathrm{M}<6.5 \\
\mathrm{M} \geq 6.0\end{array}$ & $\begin{array}{c}\mathrm{M}<6.0 \\
\mathrm{M} \geq 5.5\end{array}$ & $\begin{array}{c}\mathrm{M}<5.5 \\
\mathrm{M} \geq 5.0\end{array}$ & $\begin{array}{c}\mathrm{M}<5.0 \\
\mathrm{M} \geq 4.5\end{array}$ & $\begin{array}{c}\mathrm{M}<4.5 \\
\mathrm{M} \geq 4.0\end{array}$ \\
\hline $1897-1906$ & 1 & 0 & 3 & 2 & 1 & 0 \\
\hline $1907-1916$ & 0 & 0 & 0 & 4 & 0 & 2 \\
\hline $1917-1926$ & 3 & 1 & 7 & 4 & 3 & 1 \\
\hline $1927-1936$ & 0 & 3 & 3 & 10 & 16 & 4 \\
\hline $1937-1946$ & 3 & 2 & 2 & 3 & 6 & 1 \\
\hline $1947-1956$ & 0 & 5 & 4 & 7 & 4 & 3 \\
\hline $1957-1966$ & 3 & 1 & 3 & 6 & 18 & 15 \\
\hline $1967-1976$ & 0 & 0 & 1 & 3 & 15 & 28 \\
\hline $1977-1986$ & 0 & 0 & 0 & 4 & 24 & 40 \\
\hline $1987-1996$ & 0 & 0 & 0 & 3 & 14 & 47 \\
\hline Total & 10 & 12 & 23 & 46 & 101 & 141 \\
\hline
\end{tabular}

Figure 4. Number of earthquakes in each decade, between 1897 - 1996. (Can, [1997], p: 73) 


\section{- Climatic Data of Cyprus}

Although Cyprus is a sub-tropical country, the Mediterranean Sea is the main factor in determining the climate. This is why the climate is quite different from other sub-tropical countries. The summers are hot and humid, winters are warm with little rain. The summer seasons can extend for 5 to 6 months when there are only a few rains, days are long with a lot of sunny intervals. During the summer season (May to October) the average temperatures are $21 \mathrm{C}^{\circ}$ and the sea temperatures are above $20 \mathrm{C}^{\circ}$. The hottest months are July and August with a highest average temperature of $36 \mathrm{C}^{\circ}$ and sea temperature of $29 \mathrm{C}^{\circ}$. (Cyprus Guide CD-Rom, [1996]). Climatic elements were the most effective factors for buildings as it is mentioned in chapter four. For the Cyprus climatic elements has been presented in following first five figures.

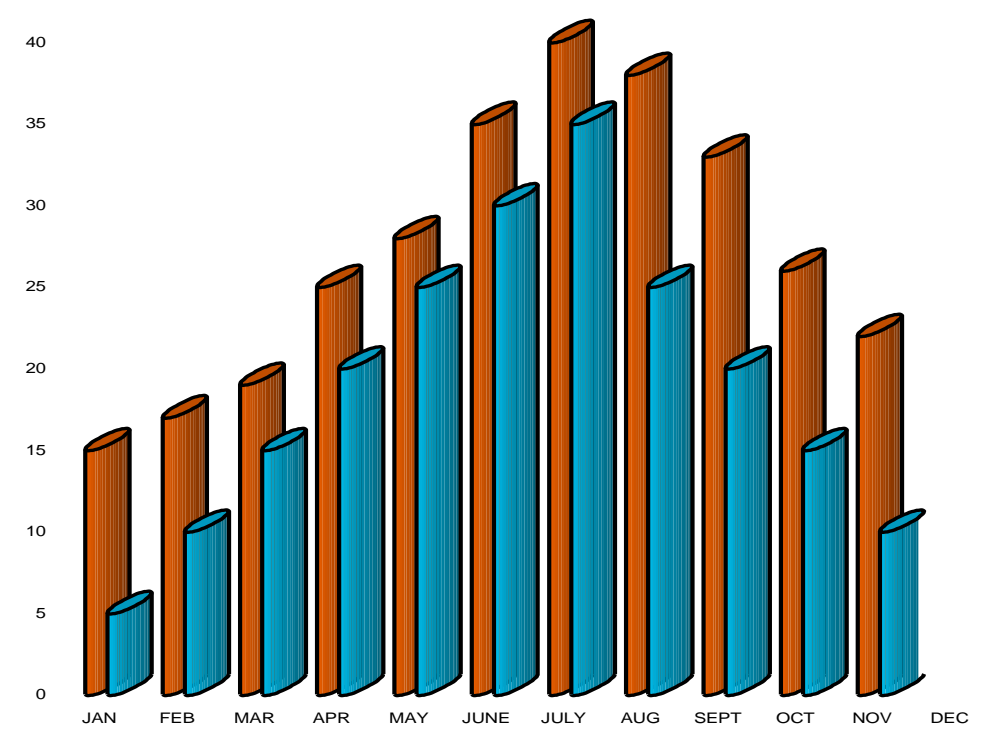

Figure 5. Mean Monthly Maximum and Minimum Air Temperatures ( C / month), (Cyprus Guide CD-Rom, [1996])

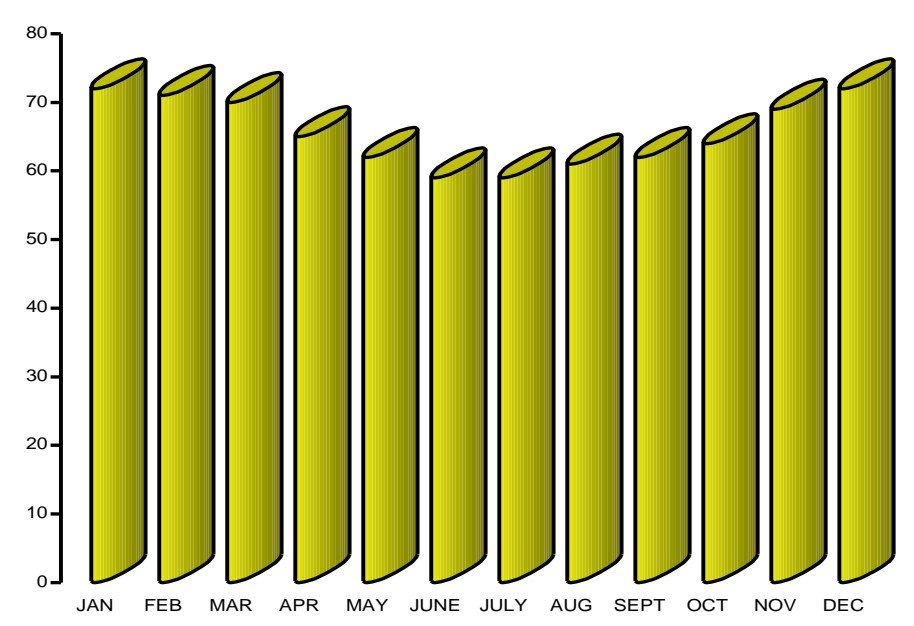

Figure 6. Bar Chard of Mean Monthly Relative Humidity (\%/month), (Cyprus Guide CD-Rom, [1996]).

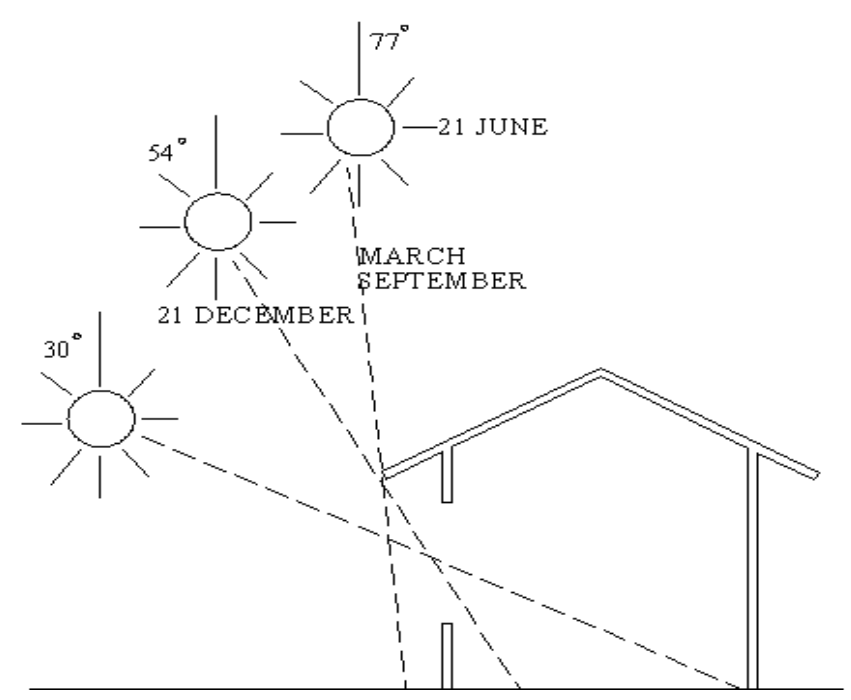

Figure 7. Sun Light coming angles for Cyprus (K.T.M.M.O.B, [1983], P: 19/10)

\section{- Site Soil investigation}

In this section the results of soil investigation for the selected site are presented, most of the primary test has been done by selecting four samples from different location (boreholes) as shown in figure (6.61)

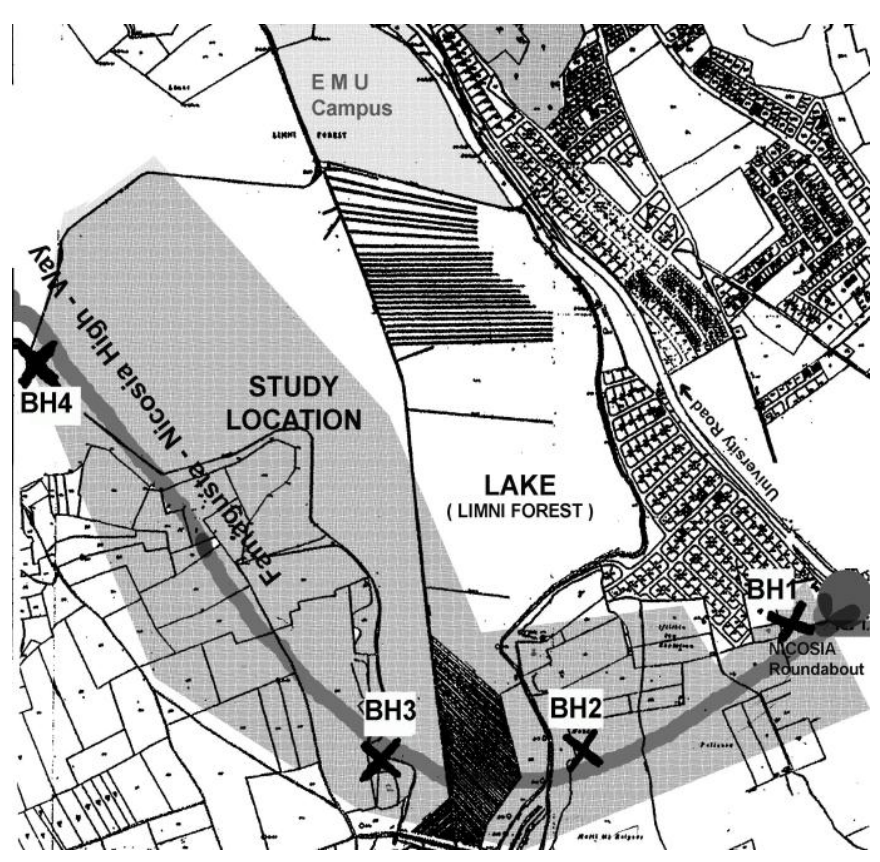

Figure 8. Location of boreholes for soil test in study location (Dinsev, [2003])

A sieve analysis has been done for each sample, and the particles of soil has been classified as coarse, or fine graded, then for the fine-graded samples hydrometer test, liquid limit, plastic limit and swelling potential has been determined for each sample. According to these results the soil classification 
International Journal of Engineering Research and Technology. ISSN 0974-3154, Volume 13, Number 10 (2020), pp. 2582-2587

(C) International Research Publication House. https://dx.doi.org/10.37624/IJERT/13.10.2020.2582-2587

for each sample has been clarified. Table 1. Summarizes all the tests results that had been done in this case study.

Table 1. Soil tests results for the selected site. (Mohd, [2003])

\begin{tabular}{|c|c|c|c|c|}
\hline \multirow{2}{*}{ TYPE of TESTS (Analysis) } & \multicolumn{4}{|c|}{ BORE HOLES NUMBER } \\
\hline & BH1 & BH2 & BH3 & BH3 \\
\hline \multicolumn{5}{|l|}{ Sieving Analysis Results } \\
\hline $4.75 \mathrm{~mm}(\mathrm{No}: 4)$ retained, $\%$ & 0 & 3 & 0 & 0 \\
\hline $0.075 \mathrm{~mm}$ (No: 200) passed, $\%$ & 93.2 & 76 & 85 & 6.3 \\
\hline \multicolumn{5}{|l|}{ Atterberg's limits } \\
\hline Liquid Limit (LL), \% & 41 & 36 & 40 & - \\
\hline Plastic Limits (kneaded limits), \% & 19.0 & 18 & 19 & - \\
\hline Plasticity Index (PI), \% & 22 & 18 & 21 & - \\
\hline \multicolumn{5}{|l|}{ Classification } \\
\hline Soil Classification & CL & CL & $\mathrm{CL}$ & SP-SM \\
\hline \multicolumn{5}{|l|}{ Swelling Percentage } \\
\hline Swelling, \% & 1.46 & 5 & 2.5 & 0 \\
\hline Problem & $\begin{array}{c}\text { Marginal } \\
\text { Expansive } \\
\text { Soil }\end{array}$ & $\begin{array}{c}\text { High } \\
\text { Expansive } \\
\text { soil }\end{array}$ & $\begin{array}{c}\text { High } \\
\text { Expansive } \\
\text { soil }\end{array}$ & $\begin{array}{l}\text { Very low } \\
\text { Expansive } \\
\text { soil }\end{array}$ \\
\hline \multicolumn{5}{|l|}{ Depth of the Boreholes } \\
\hline Average Depth (m) & $-10,-15$ & $-10,-15$ & $-10,-15$ & $-10,-15$ \\
\hline
\end{tabular}

It is clear that the soil of the chosen site is a problematic soil, Most of the samples shows that soils are classified as finegrained soil, and at the same time can be considered as expansive and collapsible soil, expansive soils cause more damage to structures, particularly light buildings and pavement, than any other natural hazard, including earthquakes and floods, whole collapsible soil may cause high differential movements in structures as a result of excessive heave or settlement.

\section{THE OPTIMAL STRUCTURAL SYSTEMS FOR FAMAGUSTA AND SELECTED SITE}

The analysis shows that the building should have a very good earthquake resistance because the selected site rest in the first earthquake zone, and at the same time any building in the given site should have a climatic consideration because Cyprus can be considered as arid zone, but the characteristics of temperate and tropic climates sometimes occurs relatively. In addition, the site which has been selected can be categorized as problematic site from soil considerations (expansive and collapsible).

Earthquake Resistance - Dynamic loads on buildings require provision for increased stiffness of individual members and for the structural system to transfer loads readily throughout the structure. By having a structure with continues (rigidity connected) joints, a building becomes better able to resist the effects of seismic loading. Poured concrete buildings which are monolithic and therefore intrinsically continuous, are excellent in this regard. Provision for this major short lived lateral loads must be made in certain designated areas of the globe where passed experiences and geological structure suggest the probability of earthquake.

Arid Climate A number of configurations of passive devices can be used depending on facade orientation. Shading blocks insulation in summer and prevents heat penetration of the building all year round in the tropics and in summer temperate zones. In general, cross ventilation should supply letting fresh air in and exhausting hot room air. Good air movement promotes heat emission from the human body surface and gives a feeling of comfort.

To come over the arid climate problems; the following points can be used to have maximizing the solutions:

- Windows opposite each other to allow crossventilation;

- Long, narrow floor-plan in sleeping zone, to maximize through ventilation in bedrooms;

- Open-plan living areas with high ceilings, to 
maximize air movement and reduce radiant heat to occupants

- Choose window type for good airflow eg, louvers rather than awning/hopper windows;

- Elevate house to catch the breezes (in areas prone to tropical cyclones, there is a trade-off - construction cost increases);

- Extra ventilation from ceiling fans, rotary vents and wind traps will be a bonus;

- Boundary fences should not block airflow (a low cyclone-wire fence is preferable to a high brick wall;

- Make sure that your garden layout hasn't blocked the summer breezes;

- In a new subdivision, the spacing of buildings should be carefully considered to avoid obstruction of the wind;

- Air movement means that mosquitoes and sand flies will be less likely to linger around the house - they prefer still air.

- materials with heat-storage capacity such as bricks and concrete are of little benefit, particularly for bedrooms - a lighter house construction (timber, fibro) will cool quicker at night;

Climate is warm all year; building heat gain should be minimized by:

- Orienting the long axis of the house east-west. The long north- and south-facing walls can easily be shaded by the eaves;

- keeping windows on east and west walls to a minimum;

- shading the walls and windows - use shutters, verandahs, canopies and/or eaves and fixed overhangs;

- using pale colors for walls and roof, to reflect the heat of the sun;

- reflective foil insulation is good, because it reflects incoming sunshine, but bulk insulation is not desirable, because it prevents the house cooling down at night;

- ventilation of the roof space, to reduce heat build-up there: the increased heat loss in the cooler season is not important;

- metal roofs which cool rapidly at night. Daytime heat gain can be minimized by using sheeting with a reflective coating on its underside.

The Optimal Building Orientations for Warm and Humid Climates - The settlement of the building should not be placed without considering of orientation. Different climatic zones have different conditions. Orientation should be considering for sunlight, cross ventilation and day - night factors. The following figure shows the optimal building orientations for warm and humid climates (Cyprus).

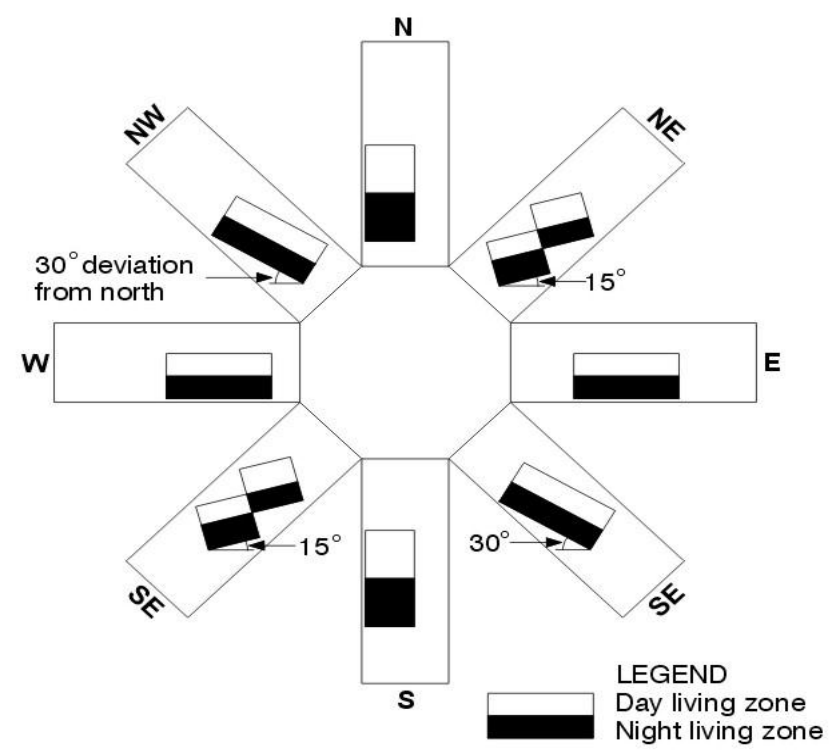

Suitable outline house plans for different site orientations

Figure 9. Optimal building orientations for warm and humid climates. (Watson,[1983])

Problematic Soil - In many countries including Cyprus there are types of soils that make foundation construction extremely difficult. As an example of these soil types expansive and collapsible soil which may cause high differential movement in the structure as a result of differential settlement.

In several instant, continuous foundations may be safer over collapsible soil than isolated foundations, if large settlements are expected, drilled-pier and pile foundations may be considered, if the soil possesses a marginal or high swell potential, precautions need to be taken. This may entail by, replacing the expansive soil under foundation, changing the nature of the expansive soil, or strengthening the structures to withstand heave, constructing structures that are flexible enough to withstand the differential soil heave without failure, or constructing deep foundation below the depth of the active zone.

Optimal Structural System Choice- Heaving established the above criteria and using number of basic structural systems. It can be shown that the optimal structural system that recommended to be used in the selected site is semi - surface active structure systems or section active systems using concrete with superplasticizers (F. M. Hassouna and H. AbuZant), with Higher Performance and Less Thickness Concrete (Hassouna, F. M., \&amp; Jung, Y. W. (2020).) providing that this system will be strengthen by bracing or by shear walls because, these types of structures can be considered to have a good earthquake resistance and at the same time, it will give a complete freedom for opening design within the external walls of the buildings, which is necessary to provide a good 
climatic design (shading and cross ventilation) as discussed before. These two types of superstructures should be based on a waffle slab mat (surface active) foundation if the structure consider to be light (low storey buildings) and it has to rest on a pile (semi section and semi surface active) foundation system if a structure will be heavy structures.
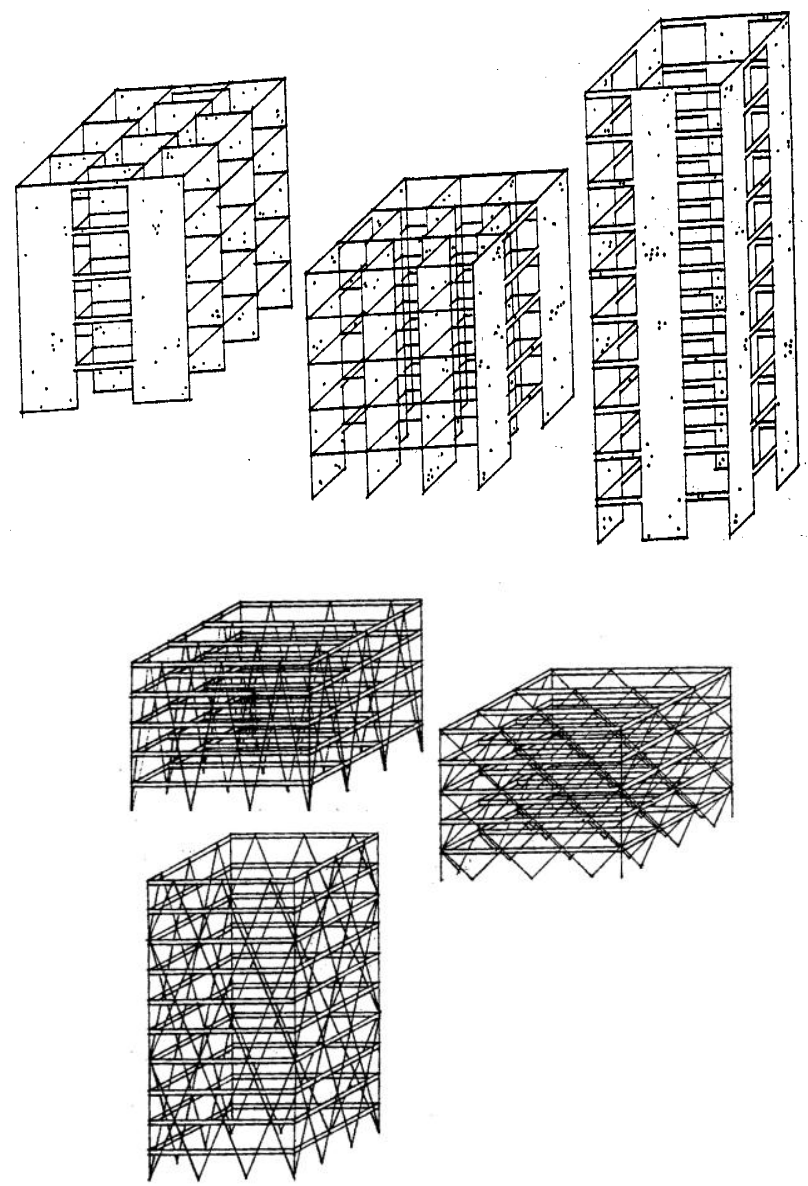

Figure 10. Reccommended type of superstructures for the selected site. (Engel, [1997], p: 272 )

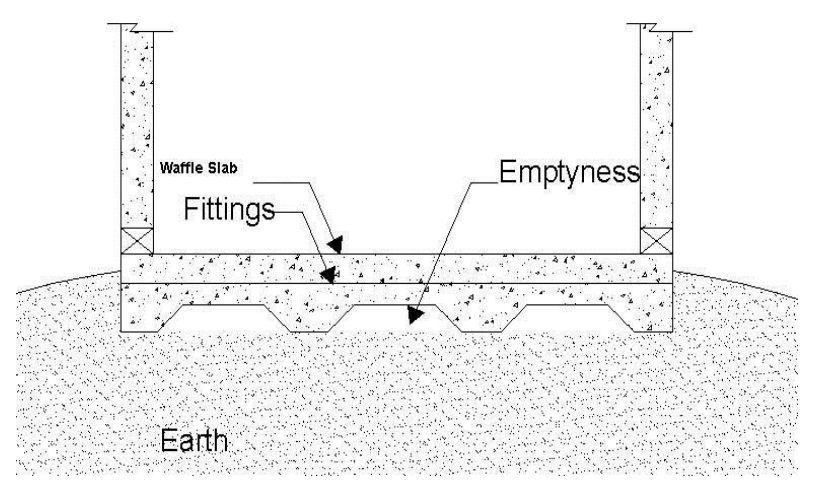

Figure 11. Surface Active, Mat foundations with waffle slab. (Drawing by Dinsev, [2003])
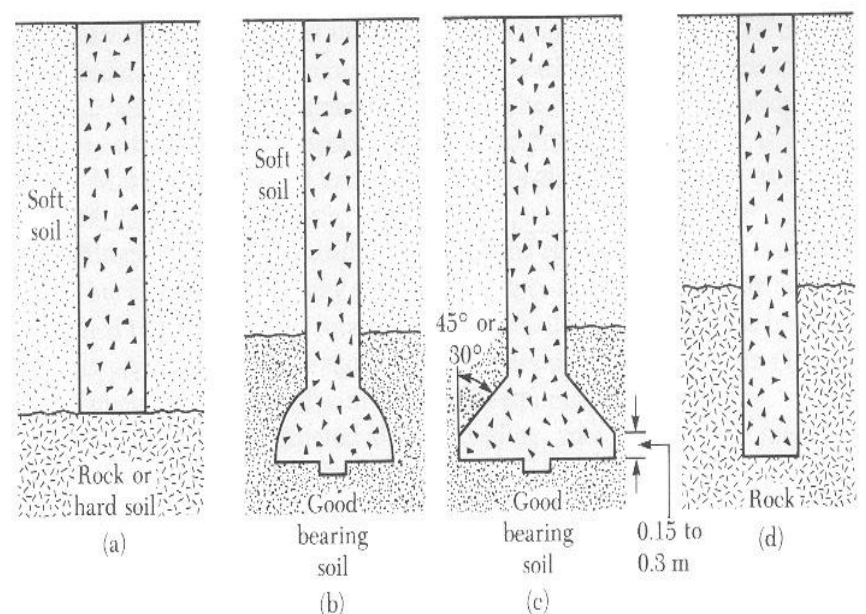

Figure 12. Semi surface and Semi section active, Drilled Pier or Pile foundations. (Braja, [1990], p:525)

\section{REFERENCES}

[1] Braja M. D, "Priniples of Foundation Engineering" , PWS - Kent Publishing Company, Wadsworth, USA, Second Eddition, 1990

[2] Can Ö., "Assessment of Seismic Hazard for Cyprus", Eastern Mediterranean University, Department of Civil Engineering, Famagusta, unpublished master thesis

[3] Cernica J. N., "Foundation Design" , Geotechnical Engineering, John Wiley \& Sons Inc., Youngstown State University, Department of Civil Engineering, P.E, Ph.D, USA, 1995

[4] Dowrick, D. J., "Earthquake Resistant Design," John Wiley \& Sons, New York, 1977

[5] Engel H., "Structure Systems", Published by Gerd Hatje, Pinted by Max Dorn Press, Germany, 1997

[6] Goulding J. R., "Energy in Architecture", The European Passive Solar Handbook, Owenlevis, 1994

[7] Watson D., Labs K." Climatic Building Design" Energy Efficiency Building Principles and Practice, by McGraw - Hill Inc, United States of America, 1983

[8] F. M. Hassouna and H. Abu-Zant, "Effects of superplasticizers on fresh and hardened Portland cement concrete characteristics," International Journal of Applied Science and Technology, vol. 5, no. 2, pp. 32-36, 2016.

[9] Hassouna, F. M., \&amp; Jung, Y. W. (2020). Developing a Higher Performance and Less Thickness Concrete Pavement: Using a Nonconventional Concrete Mixture. Advances in Civil Engineering, 2020, 1-8. doi:10.1155/2020/8822994 